\title{
高強度熱間鍛造クラッキング コンロッド用鋼の開発
}

\author{
佐 野 直 幸* \\ 長谷川 達 也䦼 \\ 飯田善 次*** 高田 健太郎***
}

\section{1. はじめに}

コンロッド(コネクティングロッド) とはエンジン内でのピ ストンの往復運動をクランクシャフトの回転運動に変換して 動力を伝達する部品である. 近年, 自動車用エンジンの高出 力化や軽量化の要求に応えるためにコンロッドにおいてもさ らなる高強度化が求められるとともに，製造工程における $\mathrm{CO}_{2}$ 排出量やコス卜を削減するために熱処理を含めた工程そ のものの合理化も求始れている. すなわち, 焼入れ焼き戻 しといった熱処理を省略しても高強度が得られる非調質鋼の 材料開発と製造工程を簡略化できるような工法の採用の両立 が課題となっていた.ロッドとキャップを一体鍛造した後に それらを破断分割(クラッキング)するクラッキング工法(図 1)は，合わせ面の加工や位置決めピンの使用を省略でき製造 工程の大幅な簡略化が可能となる.クラッキング工法そのも のは既に欧米で採用事例があるが高炭素鋼 (0.7 mass\%Cべ 一ス)を用いているため機械加工性に課題が残る上，強度も 通常の中炭素非調質鋼と同等レベルにとど屯っていたので， 国内では広く普及するには至っていなかった。 今回，中炭素 のフェライトーパーライト組織の非調質状態でも従来の調質 鋼と同等以上の強度が得られ, 同時に, クラッキング工法が 適用できる高強度熱間鍛造クラッキングコンロッド用鋼を開 発したので，その概要を紹介する。

\section{2. 開発鋼の特徵}

開発鋼の代表的な化学成分を表 1 に示す。パーライト組織

* 住友金属工業株式会社総合技術研究所主任研究員

** 株式会社住友金属小倉商品開発部参事

*** 株式会社本田技術研究所研究員

Development of High-strength Hot-forged Steel for the Application of Fracture Splitting Connecting Rod; Naoyuki Sano*, Tatsuya Hasegawa**, Zenji Iida****, Kentaro Takada***(*Sumitomo Metal Industries, Ltd., **Sumitomo Metals Kokura, Ltd., ***Honda R\&D Co. Ltd.) 2006年10月26日受理

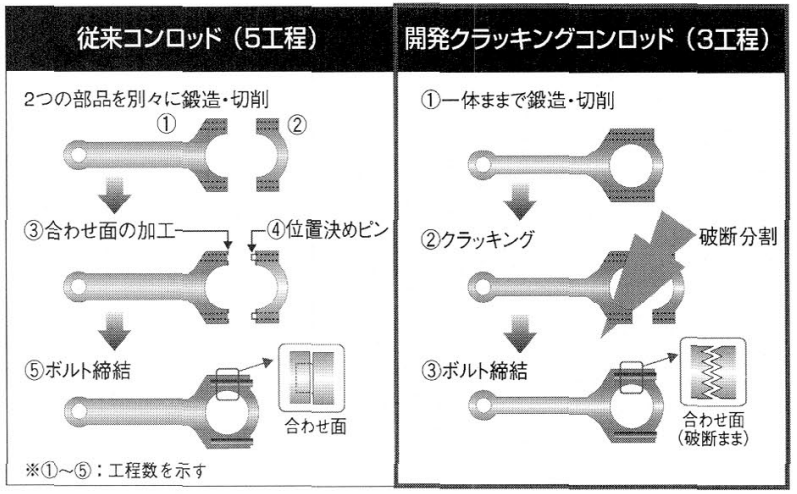

図 1 コンロッドの従来製法とクラッキング工法.

表 1 開発鋼の化学成分 (mass\%).

\begin{tabular}{ccccccc}
\hline \hline $\mathrm{C}$ & $\mathrm{Si}$ & $\mathrm{Mn}$ & $\mathrm{P}$ & $\mathrm{S}$ & $\mathrm{Ti}$ & $\mathrm{V}$ \\
\hline 0.28 & 0.55 & 0.75 & 0.05 & 0.1 & 0.17 & 0.17 \\
\hline
\end{tabular}

が多い上耐久比が低下し，機械加工性も劣化するため炭素濃 度を $0.28 \%$ に設定している. Si 抢よび Mn は一般的な機械 構造用鋼並久である。フェライは強度が低く延性が高いの で，フェライトの体積分率が増大する本開発鋼では高強度化 のためにはフェライトの強化を，クラッキング性確保のため にはフェライトの低勒化が必要となる。これらを達成するた めに Ti および V を添加し $\mathrm{P}$ を高目にしている。材料科学的 な観点から見た Tiおよび Vの役割は次章で詳しく述べる.

これまで被削性の観点から機械構造用鋼には鉛が添加されて きたが，鉛は環境影響物質であり自動車メーカーでは鉛フリ 一化を志向する動きが活発になっている，本開発鋼でも鉛を 非添加としており，そのかわり被削性の確保に硫化物を活用 する目的で $\mathrm{S}$ 量を0.1\%に増大している。

開発鋼の代表的な機械的特性を表 2 に示す。表 2 の結果 は一般的な熱間鍛造を模擬した条件で作製した試料によるも ので，例えば， $1250^{\circ} \mathrm{C}$ に加熱保持した $55 \mathrm{~mm}$ 角の角棒を直 
表 2 開発鋼の機械的特性.

\begin{tabular}{|c|c|c|c|c|}
\hline 引張り強度 $(\mathrm{MPa})$ & $10^{7}$ 回疲労強度 $(\mathrm{MPa})$ & 耐久比 & シャルピ一衝撃值* $\left(\mathrm{J} / \mathrm{cm}^{2}\right)$ & HRC 硬ざ \\
\hline $850 \sim 900$ & $420 \sim 450$ & 約 0.50 & $3 \sim 10$ & $24 \sim 27$ \\
\hline
\end{tabular}

*Vノッチ, 室温

径 $40 \mathrm{~mm}$ の丸棒に熱間鍛造して室温まで自然空冷したり強 制風冷した素材から各種試験片を作製した。 コンロッドに要 求される高い疲労強度と座屈強度が確保され, 低いシャルピ 一衝撃値は良好なクラッキング性を裏付けている。

図 2(1) ${ }^{(1)} \mathrm{V}$ 量を変化させた時の引張り強度とシャルピー 衝撃值の変化を $\mathrm{Ti}$ 添加 $(0.15 \%)$ の有無で比較したものであ る. $\mathrm{V}$ 添加量の増大とともに引張り強度は増大し, シャル ピー衝撃值は低下している。Ti添加の効果は引張り強度を


図 2 開発鋼の引張り強度とシャルピー衝撃值に及ぼ す $\mathrm{V}$ と $\mathrm{Ti}$ の効果 ${ }^{(1)}$.

\section{$0.14 \% \mathrm{~V}$}
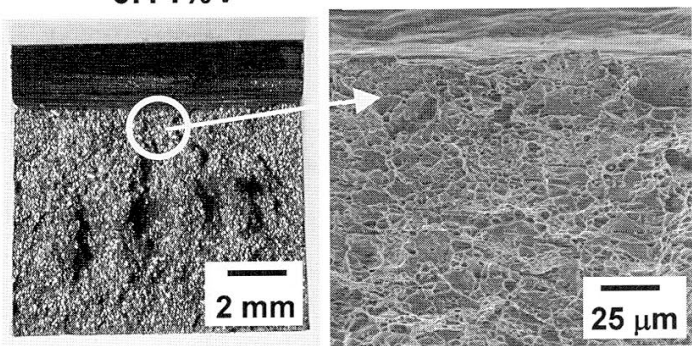

\section{$0.14 \% \mathrm{~V}-0.15 \% \mathrm{Ti}$}
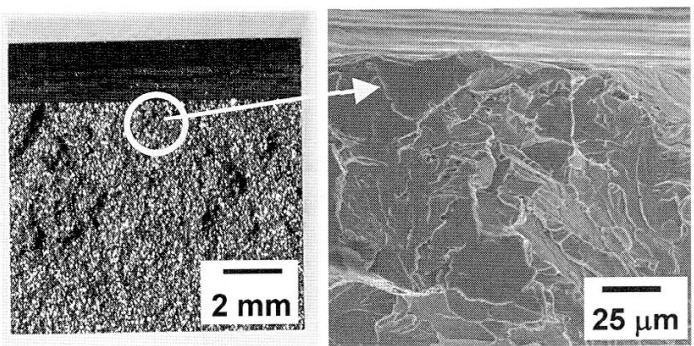

図 3 シャルピー衝撃試験(室温)による破面 ${ }^{(1)}$.
底上げし，䩲性を低下させることにあることがわかる，図 3(1)にシャルピー衝撃試験片の破面を示す、V 添加のみでは ディンプル状であった破面が Ti 添加により脆性破面に変化 していることがわかる。

\section{3. 開発鋼の高強度 . 低勒性の材料科学的考察}

開発鋼の高強度，低鞅性および被削性の三つをバランスさ せている材料科学的な因子は, 炭・窒化物と硫化物の制御に あり，化学成分の観点からは V と Tiの複合添加抢よび高目 の $\mathrm{S}$ 量にある. 各種化合物の溶解度積をまとめて図 $4^{(2)-(4)}$ に示す.

鋼中に存在する硫化物は $\mathrm{Ti}$ 系の方が $\mathrm{MnS}$ 上りも安定で あるので, Ti を添加していくにつれて MnS に置換されていくが, 開発鋼では Ti 系硫化物と $\mathrm{MnS}$ が混 在した状態となっている、V 添加による強化は亜共析組成 の非調質鋼の高強度化の一般的な手法であり, オーステナイ ト域では固溶度の大きい V がフェライト変態に伴って VC 炭化物として析出することを利用している，VC炭化物はオ 一ステナイトノフライト変態界面に沿って析出し(相界面析 出 $\left.{ }^{(5)}\right)$, フェライト地とは整合関係を保つので大きな析出強

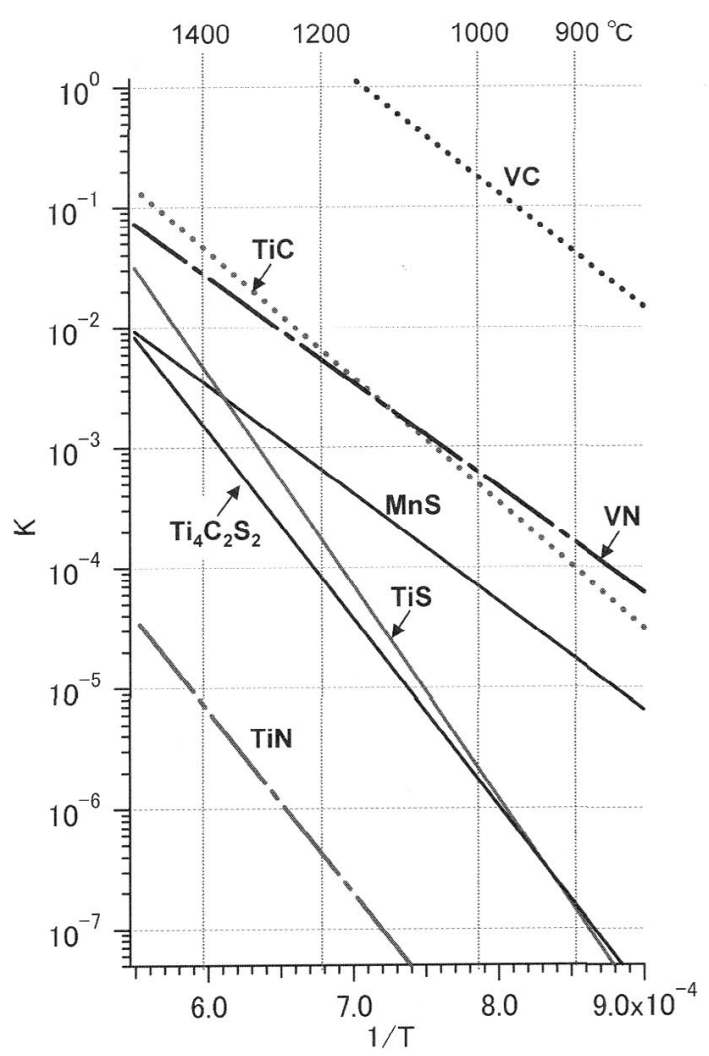

図 4 炭・窒化物抢よび硫化物の溶解度積 ${ }^{(2)-(4)}$. 
化が得られる。 TiC は VC と同じ fcc 構造を有し，格子定数 も近い(6)。図 4 加ら明らかなように, TiN の溶解度積は格 段に小さく, $\mathrm{Ti}$ 系硫化物の溶解度積も $\mathrm{TiC}$ 上り 2 桁近く小 さいので鋼中の Ti はまず窒化物や硫化物として固定され， それ以外のTiが TiCとして析出することが予想される。 $\mathrm{TiC}$ の析出のC 曲線はオーステナイト域温度にノーズを有 する(7)(8) とされているが，VCのように相界面析出するとの 報告もあり(5), 最近では Mo との複合添加の場合に列状に並 んだナノメートルオーダーの ( Ti, Mo) Cの相界面析出が熱 延鋼板の強化に大きく寄与することが報告されている( ${ }^{(9)}$. 本 開発鋼でもTi はこうした機構に類似した形で高強度化に寄 与しているものと考元られる. 熱間鍛造過程での析出機構を 明らかにするために, 鍛造温度を変化させた時の微細組織へ の影響を透過電子顕微鏡により調べた。

図 5 は熱間鍛造の際, $1250^{\circ} \mathrm{C} て ゙ 1$ 時間加熱保持後直ちに 鍛造した場合と, $900^{\circ} \mathrm{C}$ まで空冷してから鍛造した場合のフ エライト地の微細組織の TEM 写真である. $900^{\circ} \mathrm{C}$ まで空冷 してから鍛造すると微細球状炭化物のサイズが大きくなって いることがわかる、また，いずれの鍛造温度においても，微 細球状炭化物の EDX 分析結果は VC を主体としてそれに Ti
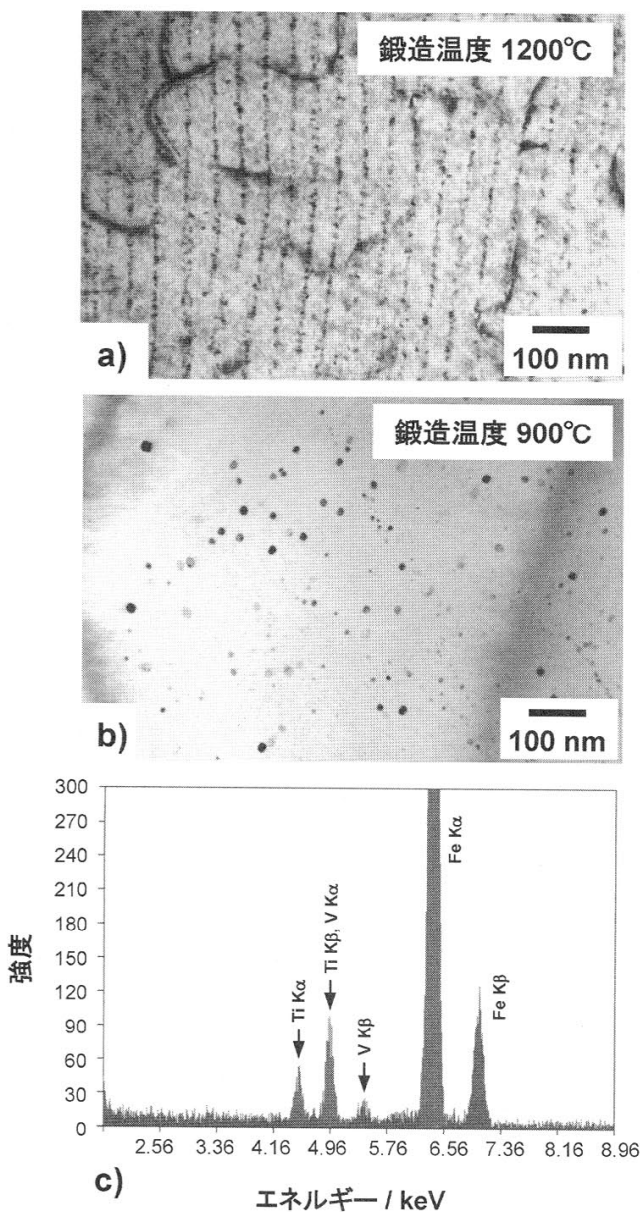

図 5 熱間鍛造温度を变化させた時のフェライト中の微 細炭化物の TEM 写真. (a) $1200^{\circ} \mathrm{C}$ 鍛造, (b) $900^{\circ} \mathrm{C}$ 鍛造, および (c) $900^{\circ} \mathrm{C}$ 鍛造材の $\mathrm{EDX}$ 分析 結果.
が混在することを示しており， $900^{\circ} \mathrm{C}$ 鍛造材における微細球 状炭化物の方が, Ti濃度が高いことが示唆された。これら の結果は以下のように解釉される(10).すなわち， $1200^{\circ} \mathrm{C}$ 近 傍の高温で加工した場合には, $\mathrm{TiC} の$ 析出開始 (PCT) 曲線 は十分長時間側にあるのでオーステナイト域での $\mathrm{TiC} の$ 析 出は抑制され，冷却過程でフェライト変態が起こる際に(VC と同様に) TiC として相界面析出, 出るいは VC中の V を置 換するようにVCに固溶して析出する。この際，TiCや VC は数 nm サイズと微細でフェライト地とは整合関保を保つの で, 強化・低勒化に寄与する。一方, $900^{\circ} \mathrm{C}$ 近傍の温度域で 加工すると $\mathrm{TiC}$ の析山が促進されてオーステナイト中にま ず TiCが析出し, フェライト変態時には目相との整合関係 が消失してしまい $\mathrm{TiC}$ の強化・低勒化への寄与も小さくな る. 加えて, 加工によって初析つェライト粒の析出開始招よ びVCの析出開始が短時間側ヘシフトし, さらにすでに存在 している $\mathrm{TiC}$ 粒子上への不均一核生成も起こる可能性があ り，これらはVCの析出開始温度を高温側へシフトさせて VCの成長を促進する。すなわち, 主要な強化機構である相 界面析出がより高温で起こってしまったり，そのための V が TiC 上への不均一核生成で消費されてしまったりする結 果, フェライト地との整合ひずみを有する数 $\mathrm{nm}$ サイズの微 細球状炭化物が得られないため十分な強化・低勒化が起こら なくなると考えられる。一般に高強度非調質鋼の製造では， 鍛造温度や冷却工程を管理することによって必要な強度特性 を得ているが，本開発鋼でも上述したような知見を踏まえて 鍛造条件を最適化して高強度化々低勒化を達成した。

\section{4. 実用化状況}

本開発鋼はすでに実用化，量産されており，本開発鋼を用 いたクラッキングコンロッドは2004年から市販の乗用車に 搭載され始めている.

\section{5. 特 許}

特開2004-301324他, 海外出願含めて18件が公開されてい る.

\section{文献}

（1）長谷川達也, 佐藤武史, 飯田善次, 高田健太郎 : 材料とプロ セス, 18(2005), 1632.

（2）成田貴一: 日本金属学会会報，8(1969)，49.

（3）上島良之, 湯山英俊, 溝口庄三, 暒岡博幸：鉄々鋼, 75 (1989), 501.

(4) W. J. Liu, S. Yue and J. J. Jonas: Metall. Trans. A, 20A(1989), 1907.

（5）大森靖也：日本金属学会会報, 15 (1976), 93.

（6）成田貴一：日本金属学会会報，7(1968), 742 .

(7) W. J. Liu and J. J. Jonas: Metall. Trans. A, 19A (1988), 1415.

(8) W. J. Liu and J. J. Jonas: Metall. Trans. A, 20A(1989), 689.

(9) Y. Funakawa, T. Shiozaki, K. Tomita, T. Yamamoto and E. Maeda: ISIJ International, 44(2004), 1945.

（10）佐野直幸, 長谷川達也：投稿準備中. 